\title{
Biological Determinants of Responsiveness to Growth Hormone: Pharmacogenomics and Personalized Medicine
}

\author{
Primus-E. Mullis
}

Paediatric Endocrinology, Diabetology and Metabolism, University Children's Hospital, Inselspital, Bern, Switzerland

\begin{abstract}
It is becoming most clear that many genes are involved in controlling the regulation of growth. Ultimately however, at the level of growth hormone $(\mathrm{GH})$, the relevant question may be not whether a patient is $\mathrm{GH}$-deficient, but whether he is $\mathrm{GH}$-responsive. As these disturbances can be divided into two gross categories, namely alterations causing subnormal GH secretion and/or those presenting with subnormal GH sensitivity/responsiveness, the main aim of this review is to focus on genes involved in growth regulation leading to short stature caused by an alteration of $\mathrm{GH}$ insensitivity/GH responsiveness; in other words, clinical circumstances where individually adapted $\mathrm{GH}$ replacement therapy may help to increase height velocity and eventually final height.

Copyright $\odot 2010$ S. Karger AG, Basel
\end{abstract}

\section{Introduction}

The most fundamental characteristic of infancy as well as childhood is growth. Although the process of growth is multifactorial and complex, the growth pattern of children, if evaluated in the context of normal standards, is rather predictable. In Switzerland for instance, the growth charts of the First Zurich Longitudinal Study of Growth and Development, where data are expressed as SDS, are used and serve the process of identifying abnormal growth well [1]. Height in a population follows approximately a gaussian distribution, similar to many other polygenetic traits. Any deviation from a normal pattern of growth can be the first manifestation of a wide variety of disease processes, including endocrine and non-endocrine disorders and, importantly, may involve any organ system of the human body.

For a considerable period of time, growth disorders were managed on the basis of a growth hormone (GH)-oriented classification system. Nowadays, however, 
clinicians are well aware that (a) GH on its own is not the major mediator of skeletal growth, (b) the tests used to diagnose GH deficiency (GHD) have many problems (see Chapter 1), and (c) many genetic defects have been described and have presented important insights into the molecular basis of GHD and non-GHD growth failure [2]. Furthermore, as pediatric endocrinologists we are regularly confronted with children presenting with short stature who are given the label of idiopathic short stature (ISS). ISS is a purely descriptive term referring to a child with a height below the age reference for population and sex, in whom with our diagnostic tools no etiological diagnosis has been made and in whom it may have to be accepted that this is the extreme of the normal distribution. Unlike hypertension there is no firm end-point to measure against so placing a cut-point for height normality becomes difficult.

One of the best known problems is to distinguish ISS from 'partial' GHD. There is no 'gold standard' to assist in GH testing as all parameters have arbitrary cut-off levels and low accuracy [3-6]. In addition, neither serum insulin-like growth factor 1 (IGF-1) nor IGF-binding protein 3 (IGFBP-3) measurements are by themselves of predictive value [7]. However, a sound clinical diagnosis is crucial before any treatment so the decision-making processes must be viewed in the total clinical setting. Here we see false-positively tested children diagnosed as 'partial GHD', whereas the false-negative ones are labeled as ISS. But it is possible that in both cases the short stature arises because of a diminished GH secretion for a given GH sensitivity.

However, as we know that recombinant human GH (rhGH) leads in almost all children to an increase of height velocity in the first year, which tapers off in the following years, we have to assume that in the vast majority of those children either the endogenous GH secretion is suboptimal for normal growth, or that the GH sensitivity/responsiveness can be increased by the administration of either physiological or pharmacological doses of rhGH. Moreover, even at the level of GH, many genes are involved in controlling growth regulation. As these disturbances can be divided into two gross categories, namely alterations causing subnormal GH secretion and/or subnormal GH sensitivity/responsiveness, the main aim of this review is to focus on genes involved in growth regulation leading to short stature caused by an alteration of GH insensitivity/GH responsiveness. In these clinical circumstances, individually adapted GH replacement therapy may help to increase height velocity and eventually final height [8] although as discussed in Chapter 2 the two may not be synonymous.

\section{Pharmacogenomics of Growth}

Pharmacogenetics (impact of one gene) and pharmacogenomics (impact of several genes, genome) is the study how a person's gene/genome can influence his/ 
her response to medication [9]. Based on the research in the field of GHD, we know that GHD is quite heterogeneous in terms of etiology as well as age at diagnosis and that improvement in adult height (over and above that of the untreated state) is the major aim of treating GHD children with rhGH [10]. The final height attained as a result of intervention is influenced, in part, by the dose, injection frequency and duration of rhGH therapy. Despite optimization of these factors, a proportion of GHD patients do not reach their target height $[10,11]$.

A number of mathematical models for predicting growth and final outcome have been proposed enabling the clinician to 'personalize' the growth-promoting therapy on the grounds of efficacy and economy [12] although whether the factors identified really impact on response has not been tested in formal randomized control trials. There are several problems with these types of models:

(1) Although prediction models are useful to give an average effect, they are not individualizable.

(2) They often only focus on one outcome, usually short-term growth, whereas interest may be more centered on final height. The two need not necessarily be related and the factors that influence response in the first year of treatment may differ totally from those that lead to prediction of the individual's final height.

(3) Very few prediction models have been constructed from an a priori hypothesis and care needs to be taken that there has been no interference from other factors accompanying the disease that might affect prognosis. The problem is that importance can be ascribed to factors that are merely 'markers' for other factors of real importance. Examples of this can be seen in models which demonstrate that individuals who are extremely short, growing very poorly and whose heights are subsequently further away from their genetic height respond best to treatment. All these factors are simply a marker of 'how bad the disease is' and could perhaps be more easily summarized by a similar single factor that actually describes the severity of the condition.

(4) Rules derived from one data set may reflect associations that have occurred by chance and often result from overfitting of the data.

(5) There is always the possibility that the predictors are idiosyncratic to the population, the setting, to the clinicians or to other aspects of the original study.

The identification of these parameters is understandable as they are easy to measure as opposed underlying genetic and epigenetic factors that might explain this individual variability of GH response. However, with an increased understanding of the factors involved in human growth, these genetic and epigenetic factors may become more important and accessible. For example, based on animal knockouts and human mutational analyses the most factors/genes affecting IGF generation as well as the structure of the growth plate deserve consideration [13].

In future, therefore, the use of specifically designed and personalized prediction models may well facilitate the decision about whether the growth response 
to a given therapy (rhGH; rhIGF-1) in an individual child is appropriate or not $[14,15]$. Based on modifiable (start of treatment, optimal dose of treatment, etc.) and non-modifiable (start heights SDS, bone age, target height SDS, etc.) variables including genetic/genomic variants as well as phenotype-genotype relationship, the realistic growth potential will be calculated. With regard to GH treatment, pharmacogenomics may play, therefore, a major role in the individual response to therapy, at least in the 'sub'-group of subjects not following the current prediction models.

\section{GH Insensitivity (GHI)}

The classic phenotype of severe growth failure associated with elevated serum GH concentrations was first described by Laron et al. [16] and can be classified as primary IGF-1 deficiency $[17,18]$. Severe forms of primary IGF-1 deficiency have been observed with molecular defects involving the GH receptor (GHR), the GHR cascade and IGF-1/acid-labile subunit/IGFBP-3 ternary complex as well as the type 1 IGF receptor. Based on molecular data, defects anywhere along the pathway from GH binding to its receptor to the IGF-1 action at the growth plate may contribute to postnatal growth failure $[17,18]$. This does not include the complex biology of the growth plate manifest at present only in our understanding of the importance of the fibroblast growth factor receptor-3 in achondroplasia. Although we are accustomed to gene deletion/mutation leading to disease, there is clear evidence that either a gene haploinsufficiency, a common polymorphism and/or partially disturbed signaling pathway may impact on susceptibility to disease or modification of treatment response in a number of ways.

\section{GH Receptor}

Growth defects result from rare molecular defects including exon deletions or mutations (nonsense, frameshift, missense) of the GHR [19] are unusual in humans. Three types of GHR mutations either affecting expression, activation or signaling are specifically highlighted in this review, but consideration is also given to heterozygous forms of GHR mutations as well as polymorphism within GHR gene possibly affecting growth as exemplars of what has already been discussed.

\section{Expression Failure [20, 21]}

Inherited GHI is a heterogeneous disorder that is often caused by mutations in the coding exons or flanking intronic sequences of the GHR gene. In 4 children with GHI, Metherell et al. [21] described a novel point mutation that led to activation 
of an intronic pseudoexon resulting in inclusion of an additional 108 nt between exons 6 and 7 in the majority of GHR transcripts. This mutation lies within the pseudoexon $\left[\mathrm{A}(-1) \rightarrow \mathrm{G}(-1)\right.$ at the $5^{\prime}$ pseudoexon splice site] and, under in vitro splicing conditions, results in inclusion of the mutant pseudoexon, whereas the wild-type pseudoexon is skipped. The presence of the pseudoexon results in inclusion of an additional 36-amino-acid sequence in a region of the receptor previously alleged to be involved in homodimerization, which may be essential for signal transduction [21]. Based on functional studies, Maamra et al. [20] have shown that this elongated GHR remained trapped around the nucleus and is therefore poorly expressed at the cell membrane, reflecting a trafficking defect and, thus, reduced downstream signaling. These properties may explain the relatively mild phenotype of these subjects.

\section{Activation Failure}

The substitution of histidine for aspartate 152 (D152H GHR) has been described in a context of familial GH resistance [22]. Originally, this mutation was suggested to interfere with receptor homodimerization because it was found to abolish homodimerization of GHBPs. But later, Waters et al. $[23,24]$ showed that GHR is constitutively homodimerized at the cell membrane, which presumably involves contacts between transmembrane or juxtamembrane domains of each receptor chain. The activation process mediated by the ligand is assumed to involve a conformational change such as relative rotation of upper and lower domains of the receptor. Based on this model, D152H GHR may interfere with this conformational change.

\section{Signaling Failure}

In a short statured family, Ross et al. $[25,26]$ documented a heterozygous expression of a severely truncated GHR mutant resulting from a mutation at the splice acceptor site of exon 3. A GHR short of the cytoplasmic domain would be devoid of any signaling capacity and because internalization is also impossible, such truncated receptors accumulate at the membrane and act as dominant-negative forms [25]. Less dramatically truncated, homozygous/compound heterozygous GHR leading to GHI have been reported $[27,28]$. The truncations of the GHR were after residue 449 (nonsense sequence of residues 424-449) and 581 (nonsense sequence of residues 560-581), respectively. In both cases, STAT5 activation, a component of subsequent post-GHR signaling, was drastically impaired [29].

\section{Heterozygosities for GHR Mutations}

There are several reports presenting data on heterozygous GHR gene defects possibly leading to short stature [30-33]. Defects in the GHR gene were present at a modest frequency (approx. 30\%) in persons who were selected for short 
stature (height SDS <-2), low GH binding protein - and IGF-1 concentrations and poor height velocity. The frequency is much lower in short subjects (approx. $2 \%$ ) presenting with adequate $\mathrm{GH}$ concentrations. However, Rosenbloom et al. [34] found minimal or no effect on stature analyzing subjects presenting with heterozygous GHR gene mutations. Further, Johnston et al. [35] studied the intracellular signaling domain of the GHR in children with ISS and concluded that ISS is not related to heterozygous and/or dominant-negative GHR variants. Interestingly, in the study by Woods et al. [33] focusing on phenotype-genotype relationships the mean adult heights of both mothers and fathers were reduced when compared to British standards from 1958. These standards, however, are not ideal for comparison in view of the diverse ethnic origin of the patients, but this finding suggests the possibility of a heterozygote effect. Furthermore, among the 19 families in whom a homozygous GHR defect in the affected children was found, the height deficit between the two parents was generally not uniform, suggesting that other genes may be influencing the magnitude of heterozygote effect in each individual. Further, in this same report, certain GHR gene mutations producing the GHBP-positive phenotype, in which GH binding is normal, were described. These forms are more likely to act in a semi-dominant manner. This is because dimeric GH binding is a prerequisite for GHR activation so that mutant receptors that bind GH normally could dimerize with wild-type GHR, reducing the number of active wild-type homodimers. This hypothesis was tested, but the expected decrease in mean parental height SDS between the GHBP-positive group when compared with those in the GHBP-negative group could not be found [33].

\section{Polymorphism of the GHR}

While a mutation can change the amino acid sequence and influence the transcript function, a polymorphism is not expected to cause a major change in protein function. A polymorphism is defined as a DNA sequence variant that occurs in at least $1 \%$ of the population [36]. Polymorphisms of the GHR gene have been reported in the general population and have been described in exons 3, 6 and 10 [31]. While the latter two are classical single nucleotide polymorphisms, the polymorphism in exon 3 is an unusual one, leading to retention (full-length, fl; GHRfl) or deletion of exon 3 (d3; GHRd3), which encodes a 22-amino-acid residue sequence in the extracellular domain $[37,38]$. GHRd3 has recently been associated with the degree of height increase in response to GH replacement in children born short for gestational age (SGA), in those with ISS, and in a GHD population [39, 40]. Patients with at least one GHRd3 allele (GHRfl/GHRd3; GHRd3/GHRd3) had a significantly better first year response leading to an improved adult height on rhGH treatment than patients with homozygosity for GHRfl [39]. However, reported studies are not all consistent which may reflect 
differing populations and conditions and the high probability of false-positive results arising from post-hoc analysis particularly in small sample size populations [41-49].

In a recent study we analyzed in a total of 186 subjects the impact of GHR genotypes (GHRd3/d3; GHRd3/fl; GHRfl/fl) on growth response to rhGH replacement therapy in two groups of patients (group A: mean rhGH dose: $26.5 \mu \mathrm{g} / \mathrm{kg}$ / day, $\mathrm{n}=104$; group $\mathrm{B}: 36.5 \mu \mathrm{g} / \mathrm{kg} / \mathrm{day}, \mathrm{n}=82$ ) suffering from severe idiopathic isolated GHD (mean maximal GH peak on GH stimulation tests: 0.6 and $1.3 \mathrm{ng} / \mathrm{ml}$, respectively) [12]. Importantly, these patients were followed up to final height and were individually analyzed for the first 4 years on rhGH replacement therapy. In contrast to previous reports, the subjects with the GHRd3/d3 and GHRd3/fl were not pooled but analyzed separately $[39,45,47]$. Overall, in the subjects presenting with either the GHRd3/d3 or GHRd3/fl genotype, a significantly better response (height velocity) to the replacement therapy during the first 2 years of therapy was noted, although in the third and fourth year of therapy, this improved height velocity was observed in those patients with the GHRfl/fl genotype. Further, during the first 2 years on therapy a GHRd 3 allele-dependent effect on height was found in study A $(\mathrm{r}=0.82)$, which could not be reported in study $\mathrm{B}$, where a higher rhGH dose was used. However, at final height the effect of rhGH treatment was identical irrespective of the specific GHR genotype. Comparing the difference between final adult height SDS and the midparental target height SDS in our severely GHD patients with the large cohort of Caucasian GHD children recruited from the KIGS database, no difference was noted [50]. Similar data were previously published by the Genentech Growth Study Group underlining the effectiveness of the rhGH treatment used in our studies [10]. From these data reporting final height it can be concluded that in severe GHD subjects, the presence or absence of the GHRd3 allele has no impact on either baseline phenotype or final height, although a difference in response (height velocity a different parameter) to rhGH replacement therapy during the first years may be observed depending on the genotype.

When comparing these findings obtained from patients with severe GHD with the previous studies focusing on GHR allele genotype and response to rhGH replacement therapy, the patients, the individual conditions, their related growth disorder as well as the rhGH doses used have to be carefully analyzed [41-49]. In the first report, for instance, Dos Santos et al. [40] studied patients with either SGA or ISS so that in effect patients with normal GH secretion were treated with supraphysiological rhGH doses. Besides the various conditions studied it is also possible that the differences between the studies reported so far represent the problems of sample size. False-positive findings are more likely with small samples sizes and for quantitative trait loci phenotypic variations tend to be overestimated with small sample sizes [51, 52]. Only large-scale 
studies of well-defined conditions or pooling the data sets will help to resolve these statistical issues.

Bearing in mind that rhGH replacement and/or therapy in any subject does not result in a constant increase of height velocity over the whole duration of treatment underlines the fact that neither $\mathrm{GH}$ responsiveness nor $\mathrm{GH}$ sensitivity is constant. Dose-response relationship may vary in every specific condition with or without any underlying growth disorder. Even for a specific condition and dose-response curve, an increase of rhGH dose may well itself affect GHR sensitivity, signaling and thus response to treatment. This fact is well established in any rhGH-treated child whose response changes after the first years on treatment [12]. Moreover, the dose response of rhGH differs according to the condition that is treated. For instance, children with GHD, Turner syndrome, SGA or ISS respond differently (and the rhGH dose is adapted accordingly) but a change in GH sensitivity with treatment remains a variable. Thus, the positive effect resulting from the GHRd3 genotype may well be downregulated and/or altered when supraphysiological doses of rhGH are given. This hypothesis could explain why severe GHD subjects might present a rhGH dose-dependent GHR genotype-related effect on growth response with an apparent plateau at around $26 \mu \mathrm{g} / \mathrm{kg} /$ day $\left(16 \mathrm{IU} / \mathrm{m}^{2} /\right.$ week), whereas this effect disappears with higher rhGH doses that lie further up on the dose-response curve for this condition. Similarly, SGA children treated with higher doses of rhGH showed no difference in growth response according to the GHR exon-3 genotype in contrast to SGA children treated with lower doses $[40,41]$. Duration of GH treatment also seems to play a major role in defining the sensitivity to the GHR genotype, in addition to the etiology of the short stature and its severity.

In summary, focusing on patients with severe IGHD, we observed a GHRd3 allele dose-dependent effect in subjects treated with rhGH during the first 2 years, with significantly better responses depending on GHRd3/d3:GHRd3/fl genotype, although no difference was observed at final height. Taking all the studies focusing on isolated GHD into account it becomes clear that the final impact of the GHR genotypes on the rhGH response is minimal $[39,43,45,47]$. The same finding seems to be true for children treated suffering from SGA $[48,53]$. Given the importance of the response to attainment of final height it may, nevertheless, well be an additional variable having some impact on growth and GH sensitivity, at least at the beginning of rhGH treatment. These findings are also supported by a clinical case report of a child with GHI syndrome, caused by a compound heterozygosity of GHR gene mutation. Father (mutation in exon 4 leading to a stop codon) and mother (mutation in exon 3 leading to a stop codon) carrying either GHRfl (father) or GHRd3 (mother) were of normal stature. Therefore the authors concluded that a single copy of either GHRfl or GHRd3 is sufficient for normal growth [38]. 


\section{Altered GHR Signaling}

Defects in the GHR signaling pathway deserve further consideration given the critical role played in rodent growth. Each subunit of the dimeric GHR associates non-covalently (through its box one motif) with a molecule of cytosolic Janusfamily tyrosine kinase 2 (JAK2). Following binding of one GH molecule, the dimeric GHR undergoes conformational changes that induce transphosphorylation of JAK2 and initiation of GHR signaling. Ligand-activated JAK2 phosphorylates multiple tyrosines on the intracellular domain of the GHR, which then serve as docking sites for cytosolic components of at least three distinct signaling pathways: the signal transducer and activator of transcription (STAT), the mitogen-activated protein kinase (MAPK) and the phosphoinositide 3-kinase (PI3K) pathways. A proline-rich region in the intracellular $\mathrm{N}$-terminal domain (ND; residues 279-286 in the box one motif) seems to be required for JAK2 and MAPK activation, as well as for phosphorylation of STAT1 and STAT3; tyrosines in the C-terminal portion of the intracellular domain are essential for STAT5 activation. These signaling cascades culminate in the regulation of multiple genes [24, 29, 54]. Our understanding of each pathway for GH-promoted functions has been based predominantly on studies employing rodent models and reconstitution systems. Valuable insights can be gained from identification of defective intracellular components of GH signaling in human disorders but the pleiotropic effects of such defects often complicate characterization. To date, only a limited number of mutations of intracellular GH signaling components have been demonstrated to be convincingly associated with growth retardation.

\section{STAT5b}

The identification of, to date, 10 subjects suffering from severe growth failure associated with homozygosity for mutations of the STAT5 $b$ gene has confirmed the central role of STAT5b in the GH-induced IGF-1 expression and in mammalian postnatal growth [29]. Therefore, in this circumstance GHI is most severe.

\section{Other Defects Leading to GHI Syndromes}

So far, no reports of growth failure caused by JAK2 gene alterations have been published. Further, impaired STAT3 activation has been reported in ISS [55]. However, no mutations were identified, but following GH therapy increased IGF-1 levels in addition to an increase in height velocity was observed.

\section{PTPN11-Gene}

Noonan syndrome (OMIM: \#163950) is an autosomal dominant dysmorphic syndrome characterized by hypertelorism, a downward eyeslant, and low-set posteriorly rotated ears. Other features include short stature, a short neck with webbing 
or redundancy of skin, cardiac anomalies, epicanthic folds, deafness, motor delay, and a bleeding diathesis. Approximately $50 \%$ of cases have been associated with gain-of-function mutations of PTPN11, the gene encoding the non-receptortype protein tyrosine phosphatase src homology region 2-domain phosphatase-2 (SHP-2) [56]. This tyrosine phosphatase is involved in intracellular signaling for a variety of hormones, growth factors and cytokines. Activated SHP-2 has been implicated as a negative regulator of GH signaling, and mutations of the SHP-2binding site in the GHR prolongs GH-promoted tyrosyl phosphorylation of the GHR, JAK2 and STAT5b $[57,58]$.

Recent reports have indicated more severe stature impairment in Noonan patients with mutations in PTPN11, as well as lower serum IGF-1 and IGFBP-3 concentrations, higher $\mathrm{GH}$ concentrations and a more modest response to $\mathrm{GH}$ therapy, consistent with mild GH resistance $[59,60]$. Heterozygous mutations in the KRAS gene, downstream effector of SHP-2, were also recently reported to be associated with Noonan syndrome but the impact of such mutations on components of the GHR signaling pathway is not clear [61]. Another potential site for molecular defects of GHR signaling is suppressor of cytokine signaling-2 (SOCS2), which is involved in the negative regulation of cytokine action through the inhibition of JAKs and STATs $[62,63]$.

\section{Growth Responsiveness to GH Therapy, the Impact of the Growth Plate}

Studies are already in progress to assess both proteomic and genomic biomarkers for the evaluation and management of short stature and for the assessment of responsiveness to $\mathrm{GH}$ therapy. While mutations and polymorphisms of known genes involved in the GH/IGF-1 axis have been identified in various forms of short stature, attention should also be drawn to non-GH/IGF-related factors such as SHOX (see below), fibroblast growth factor receptor-3 [64], the C-type natriuretic peptide receptor 2 (NPR2) [65] known to affect linear growth as well as growth plate structure and impact, therefore, on the effect of GH/IGF axis as well. In addition to other factors yet to be identified, it is also very likely that epigenetic factors will provide important insights into the evaluation of short stature.

Longitudinal bone growth occurs rapidly in early life and slows down and eventually ceases at the end of puberty. This decline in growth rate is due primarily to a decrease in the rate of chondrocyte proliferation and is accompanied by a structural change in growth plate cartilage. Although in humans the age-dependent decline in growth rate is interrupted by a brief period of growth acceleration, which peaks during early to mid puberty and may partly be induced by estrogen increasing the activity of GH/IGF-1 axis $[66,67]$, this programmed senescence appears not to be caused by a systemic mechanism but rather by a mechanism intrinsic to the 
growth plate itself. Based on data focusing on growth plate senescence and hormonal impact it becomes clear that the enhanced growth responsiveness of $\mathrm{GH}$ at the young age is unlikely to be mediated by IGF-1, but appears to reside within the growth plate itself [68-70]. Any disorder at the level of growth plate is bound to result in short stature and may present with different growth responsiveness and, therefore, a given GH therapy has to be correspondingly personalized [71]. In addition, for these non-GHD conditions, GH is used in a pharmacological manner rather than as physiologic replacement, and, therefore, the GH dose is rather high in order to improve height velocity and increase final height [72].

\section{SHOX (Short Stature HOmeoboX Containing Gene; OMIM: \#312865)}

The SHOX gene was discovered in 1997 during the search for genes underlying the short stature of Turner syndrome and is located in the pseudoautosomal regions at the distal ends of the $\mathrm{X}$ and $\mathrm{Y}$ chromosome, at positions Xp22.3 and Yp11.3. The gene encodes a homeodomain transcription factor responsible for a significant proportion of long bone growth [73]. In addition to its role in explaining the growth deficit in Turner syndrome, SHOX haploinsufficiency is also the primary cause of short stature in $50-70 \%$ of individuals who have Leri-Weill dyschondrosteosis (LWD, OMIM: \#127300) and in about $2-15 \%$ of ISS [72, 74, 75].

Clinically, SHOX deficiency is associated with a broad spectrum of phenotypic effects, ranging from short stature without dysmorphic signs to profound mesomelic skeletal dysplasia, a form of short stature characterized by disproportionate shortening of the middle (mesial) segments of the upper as well as lower limbs [76]. There is strong evidence that SHOX is a major mediator of linear growth; first, it is expressed in the developing skeleton during fetal life and is specifically expressed in bone marrow fibroblasts and proliferating hypertrophic chondrocytes; second, deficiency of SHOX at the growth plate is associated with marked disorganization of chondrocyte proliferation [77], and third, there is a dose-dependent association between the number of active copies of the SHOX gene and height [78].

\section{Conclusions}

The concept that genetic variation contributes in general to variability in disease phenotypes and therefore in drug responses is widely accepted and validated in many research settings. Therefore, the identification of an association between a clinical phenotype, such as short stature, and a genetic variant, for instance within the GHR gene, or a set of genetic variants is an increasing theme also in the field of pediatric endocrinology. Although many such associations were not reproduced in subsequent studies and there are many challenges to overcome in 
the implementation of pharmacogenetic as well as pharmacogenomic vision in clinical practice, potential solutions are also evolving rapidly and may help to individualize $\mathrm{GH}$ treatment based upon well-defined $\mathrm{GH}$ responsiveness and careful genetic analysis.

\section{References}

1 Prader A, Largo RH, Molinari L, Issler C: Physical growth of Swiss children from birth to 20 years of age. First Zurich longitudinal study of growth and development. Helv Paediatr Acta Suppl 1989;52:1125.

-2 Mullis PE: Genetic control of growth. Eur J Endocrinol 2005;152:11-31.

-3 Hindmarsh P, Smith PJ, Brook CG, Matthews DR: The relationship between height velocity and growth hormone secretion in short prepubertal children. Clin Endocrinol (Oxf) 1987;27:581591.

4 Dammacco F, Boghen MF, Camanni F, Cappa M, Ferrari C, Ghigo E, Giordano G, Loche S, Minuto F, Mucci M, et al: Somatotropic function in short stature: evaluation by integrated auxological and hormonal indices in 214 children. The Italian Collaborative Group of Neuroendocrinology. J Clin Endocrinol Metab 1993;77:68-72.

5 Rogol AD, Blethen SL, Sy JP, Veldhuis JD: Do growth hormone $(\mathrm{GH})$ serial sampling, insulinlike growth factor-1 (IGF-1) or auxological measurements have an advantage over GH stimulation testing in predicting the linear growth response to GH therapy? Clin Endocrinol (Oxf) 2003;58:229237.

6 Hindmarsh P: Endocrine assessment and principles of endocrine testing; in Kelnar C, Savage M, Saenger P, Cowell C (eds): Growth disorders. London, Hodder Arnold, 2007, pp 219-229.

7 Mitchell H, Dattani MT, Nanduri V, Hindmarsh PC, Preece MA, Brook CG: Failure of IGF-1 and IGFBP-3 to diagnose growth hormone insufficiency. Arch Dis Child 1999;80:443-447.

$\checkmark 8$ Rosenfeld RG: Pharmacogenomics and pharmacoproteomics in the evaluation and management of short stature. Eur J Endocrinol 2007;157(suppl 1):S27-S31.

9 Thomas FJ, McLeod HL, Watters JW: Pharmacogenomics: the influence of genomic variation on drug response. Curr Top Med Chem 2004;4: 1399-1409.
Blethen SL, Baptista J, Kuntze J, Foley T, LaFranchi $\mathrm{S}$, Johanson A: Adult height in growth hormone (GH)-deficient children treated with biosynthetic GH. The Genentech Growth Study Group. J Clin Endocrinol Metab 1997;82:418-420.

11 Ranke MB, Lindberg A, Chatelain P, Wilton P, Cutfield W, Albertsson-Wikland K, Price DA: Derivation and validation of a mathematical model for predicting the response to exogenous recombinant human growth hormone $(\mathrm{GH})$ in prepubertal children with idiopathic GH deficiency. KIGS International Board. Kabi Pharmacia International Growth Study. J Clin Endocrinol Metab 1999;84: 1174-1183.

12 Raz B, Janner M, Petkovic V, Lochmatter D, Eble A, Dattani MT, Hindmarsh PC, Fluck CE, Mullis PE: Influence of growth hormone $(\mathrm{GH})$ receptor deletion of exon 3 and full-length isoforms on $\mathrm{GH}$ response and final height in patients with severe GH deficiency. J Clin Endocrinol Metab 2008;93: 974-980.

13 Rosenfeld RG: The pharmacogenomics of human growth. J Clin Endocrinol Metab 2006;91:795796.

14 Ranke MB, Lindberg A, Chatelain P, Wilton P, Price DA, Albertsson-Wikland K: The potential of prediction models based on data from KIGS as tools to measure responsiveness to growth hormone. Pharmacia International Growth Database. Horm Res 2001;55(suppl 2):44-48.

Weinshilboum R, Wang L: Pharmacogenomics: bench to bedside. Nat Rev Drug Discov 2004;3: 739-748.

16 Laron Z, Pertzelan A, Mannheimer S: Genetic pituitary dwarfism with high serum concentration of growth hormone - a new inborn error of metabolism? Isr J Med Sci 1966;2:152-155.

17 Rosenfeld RG, Hwa V: Toward a molecular basis for idiopathic short stature. J Clin Endocrinol Metab 2004;89:1066-1067. 
18 Rosenfeld RG, Kofoed E, Little B, Woods K, Buckway C, Pratt K, Hwa V: Growth hormone insensitivity resulting from post-GH receptor defects. Growth Horm IGF Res 2004;14(suppl A):S35-S38.

19 Bougneres P, Goffin V: The growth hormone receptor in growth. Endocrinol Metab Clin North Am 2007;36:1-16.

20 Maamra M, Milward A, Esfahani HZ, Abbott LP, Metherell LA, Savage MO, Clark AJ, Ross RJ: A 36 residues insertion in the dimerization domain of the growth hormone receptor results in defective trafficking rather than impaired signaling. J Endocrinol 2006;188:251-261.

-21 Metherell LA, Akker SA, Munroe PB, Rose SJ, Caulfield M, Savage MO, Chew SL, Clark AJ: Pseudoexon activation as a novel mechanism for disease resulting in atypical growth-hormone insensitivity. Am J Hum Genet 2001;69:641-646.

-22 Duquesnoy P, Sobrier ML, Duriez B, Dastot F, Buchanan CR, Savage MO, Preece MA, Craescu CT, Blouquit Y, Goossens M, et al: A single amino acid substitution in the exoplasmic domain of the human growth hormone $(\mathrm{GH})$ receptor confers familial GH resistance (Laron syndrome) with positive GH-binding activity by abolishing recep tor homodimerization. EMBO J 1994;13:13861395.

23 Brown RJ, Adams JJ, Pelekanos RA, Wan Y, McKinstry WJ, Palethorpe K, Seeber RM, Monks TA, Eidne KA, Parker MW, Waters MJ: Model for growth hormone receptor activation based on subunit rotation within a receptor dimer. Nat Struct Mol Biol 2005;12:814-821.

24 Waters MJ, Hoang HN, Fairlie DP, Pelekanos RA, Brown RJ: New insights into growth hormone action. J Mol Endocrinol 2006;36:1-7.

25 Ross RJ, Esposito N, Shen XY, Von Laue S, Chew SL, Dobson PR, Postel-Vinay MC, Finidori J: A short isoform of the human growth hormone receptor functions as a dominant negative inhibitor of the full-length receptor and generates large amounts of binding protein. Mol Endocrinol 1997; 11:265-273.

26 Ayling RM, Ross R, Towner P, Von Laue S, Finidori J, Moutoussamy S, Buchanan CR, Clayton PE, Norman MR: A dominant-negative mutation of the growth hormone receptor causes familial short stature. Nat Genet 1997;16:13-14.
Milward A, Metherell L, Maamra M, Barahona MJ, Wilkinson IR, Camacho-Hubner C, Savage MO, Bidlingmaier CM, Clark AJ, Ross RJ, Webb SM: Growth hormone (GH) insensitivity syndrome due to a $\mathrm{GH}$ receptor truncated after Box1, resulting in isolated failure of STAT5 signal transduction. J Clin Endocrinol Metab 2004;89:12591266.

28 Tiulpakov A, Rubtsov P, Dedov I, Peterkova V, Bezlepkina O, Chrousos GP, Hochberg Z: A novel C-terminal growth hormone receptor (GHR) mutation results in impaired GHR-STAT5 but normal STAT-3 signaling. J Clin Endocrinol Metab 2005;90:542-547.

29 Rosenfeld RG, Belgorosky A, Camacho-Hubner C, Savage MO, Wit JM, Hwa V: Defects in growth hormone receptor signaling. Trends Endocrinol Metab 2007;18:134-141.

30 Goddard AD, Dowd P, Chernausek S, Geffner M, Gertner J, Hintz R, Hopwood N, Kaplan S, Plotnick L, Rogol A, Rosenfield R, Saenger P, Mauras N, Hershkopf R, Angulo M, Attie K: Partial growth-hormone insensitivity: the role of growthhormone receptor mutations in idiopathic short stature. J Pediatr 1997;131:S51-55.

31 Goddard AD, Covello R, Luoh SM, Clackson T, Attie KM, Gesundheit N, Rundle AC, Wells JA, Carlsson LM: Mutations of the growth hormone receptor in children with idiopathic short stature. The Growth Hormone Insensitivity Study Group. N Engl J Med 1995;333:1093-1098.

\$2 Sanchez JE, Perera E, Baumbach L, Cleveland WW: Growth hormone receptor mutations in children with idiopathic short stature. J Clin Endocrinol Metab 1998;83:4079-4083.

33 Woods KA, Dastot F, Preece MA, Clark AJ, PostelVinay MC, Chatelain PG, Ranke MB, Rosenfeld RG, Amselem S, Savage MO: Phenotype:genotype relationships in growth hormone insensitivity syndrome. JClin Endocrinol Metab 1997;82:35293535.

4 Rosenbloom AL, Guevara-Aguirre J, Rosenfeld RG, Pollock BH: Growth in growth hormone insensitivity. Trends Endocrinol Metab 1994;5: 296-303.

35 Johnston LB, Pashankar F, Camacho-Hubner C, Savage MO, Clark AJ: Analysis of the intracellular signalling domain of the human growth hormone receptor in children with idiopathic short stature. Clin Endocrinol (Oxf) 2000;52:463-469. 
36 Roden DM, Altman RB, Benowitz NL, Flockhart DA, Giacomini KM, Johnson JA, Krauss RM, McLeod HL, Ratain MJ, Relling MV, Ring HZ, Shuldiner AR, Weinshilboum RM, Weiss ST: Pharmacogenomics: challenges and opportunities. Ann Intern Med 2006;145:749-757.

-37 Pantel J, Machinis K, Sobrier ML, Duquesnoy P, Goossens M, Amselem S: Species-specific alternative splice mimicry at the growth hormone receptor locus revealed by the lineage of retroelements during primate evolution. J Biol Chem 2000;275:18664-18669.

38 Pantel J, Grulich-Henn J, Bettendorf M, Strasburger CJ, Heinrich U, Amselem S: Heterozygous nonsense mutation in exon 3 of the growth hormone receptor (GHR) in severe $\mathrm{GH}$ insensitivity (Laron syndrome) and the issue of the origin and function of the GHRd3 isoform. J Clin Endocrinol Metab 2003;88:1705-1710.

- 39 Jorge AA, Marchisotti FG, Montenegro LR, Carvalho LR, Mendonca BB, Arnhold IJ: Growth hormone $(\mathrm{GH})$ pharmacogenetics: influence of $\mathrm{GH}$ receptor exon 3 retention or deletion on firstyear growth response and final height in patients with severe GH deficiency. J Clin Endocrinol Metab 2006;91:1076-1080.

- 40 Dos Santos C, Essioux L, Teinturier C, Tauber M, Goffin V, Bougneres P: A common polymorphism of the growth hormone receptor is associated with increased responsiveness to growth hormone. Nat Genet 2004;36:720-724.

- 41 Carrascosa A, Esteban C, Espadero R, FernandezCancio M, Andaluz P, Clemente M, Audi L, Wollmann H, Fryklund L, Parodi L: The d3/fl-growth hormone $(\mathrm{GH})$ receptor polymorphism does not influence the effect of $\mathrm{GH}$ treatment $(66 \mu \mathrm{g} / \mathrm{kg}$ per day) or the spontaneous growth in short non$\mathrm{GH}$-deficient small-for-gestational-age children: results from a two-year controlled prospective study in 170 Spanish patients. J Clin Endocrinol Metab 2006;91:3281-3286.

42 Binder G, Baur F, Schweizer R, Ranke MB: The d3-growth hormone $(\mathrm{GH})$ receptor polymorphism is associated with increased responsiveness to GH in Turner syndrome and short small-forgestational-age children. J Clin Endocrinol Metab 2006;91:659-664.

43 Pilotta A, Mella P, Filisetti M, Felappi B, Prandi E, Parrinello G, Notarangelo LD, Buzi F: Common polymorphisms of the growth hormone $(\mathrm{GH})$ receptor do not correlate with the growth response to exogenous recombinant human $\mathrm{GH}$ in $\mathrm{GH}$ deficient children. J Clin Endocrinol Metab 2006; 91:1178-1180.
Audi L, Esteban C, Carrascosa A, Espadero R, Perez-Arroyo A, Arjona R, Clemente M, Wollmann H, Fryklund L, Parodi LA: Exon 3-deleted/ full-length growth hormone receptor polymorphism genotype frequencies in Spanish short small-for-gestational-age (SGA) children and adolescents $(\mathrm{n}=247)$ and in an adult control population $(\mathrm{n}=289)$ show increased $\mathrm{fl} / \mathrm{fl}$ in short SGA. J Clin Endocrinol Metab 2006;91:5038-5043.

45 Blum WF, Machinis K, Shavrikova EP, Keller A, Stobbe H, Pfaeffle RW, Amselem S: The growth response to growth hormone $(\mathrm{GH})$ treatment in children with isolated GH deficiency is independent of the presence of the exon 3-minus isoform of the GH receptor. J Clin Endocrinol Metab 2006;91:4171-4174.

46 Audi L, Carrascosa A, Esteban C, FernandezCancio M, Andaluz P, Yeste D, Espadero R, Granada ML, Wollmann H, Fryklund L: The exon 3-deleted/full-length growth hormone receptor polymorphism does not influence the effect of puberty or growth hormone therapy on glucose homeostasis in short non-growth hormone-deficient small-for-gestational-age children: results from a two-year controlled prospective study. J Clin Endocrinol Metab 2008;93:2709-2715.

Van der Klaauw AA, van der Straaten T, BaakPablo R, Biermasz NR, Guchelaar HJ, Pereira AM, Smit JW, Romijn JA: Influence of the d3-growth hormone $(\mathrm{GH})$ receptor isoform on short-term and long-term treatment response to $\mathrm{GH}$ replacement in GH-deficient adults. J Clin Endocrinol Metab 2008;93:2828-2834.

48 Carrascosa A, Audi L, Fernandez-Cancio M, Esteban C, Andaluz P, Vilaro E, Clemente M, Yeste D, Albisu MA, Gussinye M: The exon 3-deleted/full-length growth hormone receptor polymorphism did not influence growth response to growth hormone therapy over two years in prepubertal short children born at term with adequate weight and length for gestational age. J Clin Endocrinol Metab 2008;93:764-770.

Toyoshima MT, Castroneves LA, Costalonga EF, Mendonca BB, Arnhold IJ, Jorge AA: Exon 3-deleted genotype of growth hormone receptor (GHRd3) positively influences IGF-1 increase at generation test in children with idiopathic short stature. Clin Endocrinol (Oxf) 2007;67:500-504.

50 Reiter EO, Price DA, Wilton P, Albertsson-Wikland K, Ranke MB: Effect of growth hormone (GH) treatment on the near-final height of 1258 patients with idiopathic GH deficiency: Analysis of a large international database. J Clin Endocrinol Metab 2006;91:2047-2054. 
$51 \mathrm{Xu}$ S: Theoretical basis of the Beavis effect. Genetics 2003;165:2259-2268.

52 Beavis W: QTL analyses: power, precision and accuracy; in Paterson A (ed): Molecular Dissection of Complex Traits. Boca Raton, CRC Press, 1998, pp 145-161.

53 Carrascosa A, Audi L, Esteban C, FernandezCancio M, Andaluz P, Gussinye M, Clemente M, Yeste D, Albisu MA: Growth hormone (GH) dose, but not exon 3-deleted/full-length GH receptor polymorphism genotypes, influences growth response to two-year GH therapy in short smallfor-gestational-age children. J Clin Endocrinol Metab 2008;93:147-153.

54 Zhu T, Goh EL, Graichen R, Ling L, Lobie PE: Signal transduction via the growth hormone receptor. Cell Signal 2001;13:599-616.

55 Rojas-Gil AP, Ziros PG, Diaz L, Kletsas D, Basdra EK, Alexandrides TK, Zadik Z, Frank SJ, Papathanassopoulou V, Beratis NG, Papavassiliou AG, Spiliotis BE: Growth hormone/JAK-STAT axis signal-transduction defect. A novel treatable cause of growth failure: FEBS J 2006;273:34543466.

56 Tartaglia M, Kalidas K, Shaw A, Song X, Musat DL, van der Burgt I, Brunner HG, Bertola DR, Crosby A, Ion A, Kucherlapati RS, Jeffery S, Patton MA, Gelb BD: PTPN11 mutations in Noonan syndrome: molecular spectrum, genotype-phenotype correlation, and phenotypic heterogeneity. Am J Hum Genet 2002;70:1555-1563.

57 Carter-Su C, Rui L, Stofega MR: SH2-B and SIRP: JAK2 binding proteins that modulate the actions of growth hormone. Recent Prog Horm Res 2000; 55:293-311.

58 Stofega MR, Herrington J, Billestrup N, Carter-Su C: Mutation of the SHP-2 binding site in growth hormone (GH) receptor prolongs GH-promoted tyrosyl phosphorylation of GH receptor, JAK2, and STAT5b. Mol Endocrinol 2000;14:13381350.

-59 Binder G, Neuer K, Ranke MB, Wittekindt NE: Ptpn 11 mutations are associated with mild growth hormone resistance in individuals with Noonan syndrome. JClin Endocrinol Metab 2005;90:53775381.

60 Limal JM, Parfait B, Cabrol S, Bonnet D, Leheup B, Lyonnet S, Vidaud M, Le Bouc Y: Noonan syndrome: relationships between genotype, growth, and growth factors. J Clin Endocrinol Metab 2006;91:300-306.
61 Schubbert S, Zenker M, Rowe SL, Boll S, Klein C, Bollag G, van der Burgt I, Musante L, Kalscheuer V, Wehner LE, Nguyen H, West B, Zhang KY, Sistermans E, Rauch A, Niemeyer CM, Shannon K, Kratz CP: Germline KRAS mutations cause Noonan syndrome. Nat Genet 2006;38:331-336.

62 Metcalf D, Greenhalgh CJ, Viney E, Willson TA, Starr R, Nicola NA, Hilton DJ, Alexander WS: Gigantism in mice lacking suppressor of cytokine signalling-2. Nature 2000;405:1069-1073.

63 Greenhalgh CJ, Rico-Bautista E, Lorentzon M, Thaus AL, Morgan PO, Willson TA, Zervoudakis P, Metcalf D, Street I, Nicola NA, Nash AD, Fabri LJ, Norstedt G, Ohlsson C, Flores-Morales A, Alexander WS, Hilton DJ: SOCS2 negatively regulates growth hormone action in vitro and in vivo. J Clin Invest 2005;115:397-406.

64 Vajo Z, Francomano CA, Wilkin DJ: The molecular and genetic basis of fibroblast growth factor receptor-3 disorders: the achondroplasia family of skeletal dysplasias, Muenke craniosynostosis, and Crouzon syndrome with acanthosis nigricans. Endocr Rev 2000;21:23-39.

65 Olney RC, Bukulmez H, Bartels CF, Prickett TC, Espiner EA, Potter LR, Warman ML: Heterozygous mutations in natriuretic peptide receptor-B (NPR2) are associated with short stature. J Clin Endocrinol Metab 2006;91:1229-1232.

66 Tanner JM: The regulation of human growth. Child Dev 1963;34:817-847.

67 Cutler GB Jr: The role of estrogen in bone growth and maturation during childhood and adolescence. J Steroid Biochem Mol Biol 1997;61:141144.

68 Nilsson O, Baron J: Impact of growth plate senescence on catch-up growth and epiphyseal fusion. Pediatr Nephrol 2005;20:319-322.

69 Nilsson O, Marino R, De Luca F, Phillip M, Baron $\mathrm{J}$ : Endocrine regulation of the growth plate. Horm Res 2005;64:157-165.

70 Emons JA, Boersma B, Baron J, Wit JM: Catch-up growth: testing the hypothesis of delayed growth plate senescence in humans. J Pediatr 2005;147: 843-846.

71 Davenport ML, Crowe BJ, Travers SH, Rubin K, Ross JL, Fechner PY, Gunther DF, Liu C, Geffner ME, Thrailkill K, Huseman C, Zagar AJ, Quigley CA: Growth hormone treatment of early growth failure in toddlers with Turner syndrome: a randomized, controlled, multicenter trial. J Clin Endocrinol Metab 2007;92:3406-3416. 
72 Quigley CA: Growth hormone treatment of nongrowth hormone-deficient growth disorders. Endocrinol Metab Clin North Am 2007;36:131186.

73 Rao E, Weiss B, Fukami M, Rump A, Niesler B, Mertz A, Muroya K, Binder G, Kirsch S, Winkelmann M, Nordsiek G, Heinrich U, Breuning MH, Ranke MB, Rosenthal A, Ogata T, Rappold GA: Pseudoautosomal deletions encompassing a novel homeobox gene cause growth failure in idiopathic short stature and Turner syndrome. Nat Genet 1997;16:54-63.

74 Huber C, Rosilio M, Munnich A, Cormier-Daire $\mathrm{V}$ : High incidence of SHOX anomalies in individuals with short stature. J Med Genet 2006; 43:735-739.

75 Blum WF, Crowe BJ, Quigley CA, Jung H, Cao D, Ross JL, Braun L, Rappold G: Growth hormone is effective in treatment of short stature associated with short stature homeobox-containing gene deficiency: two-year results of a randomized, controlled, multicenter trial. J Clin Endocrinol Metab 2007;92:219-228.
76 Rappold G, Blum WF, Shavrikova EP, Crowe BJ, Roeth R, Quigley CA, Ross JL, Niesler B: Genotypes and phenotypes in children with short stature: clinicalindicators ofSHOX haploinsufficiency. J Med Genet 2007;44:306-313.

77 Marchini A, Rappold G, Schneider KU: SHOX at a glance: From gene to protein. Arch Physiol Biochem 2007;113:116-123.

78 Ogata T, Matsuo N, Nishimura G: SHOX haploinsufficiency and overdosage: impact of gonadal function status. J Med Genet 2001;38:1-6.

Primus-E. Mullis

Paediatric Endocrinology, Diabetology and Metabolism

University Children's Hospital, Inselspital

$\mathrm{CH}-3010$ Bern (Switzerland)

Tel. +41 31632 9552, Fax +41 31632 9550, E-Mail primus.mullis@insel.ch 